\title{
Writing Lines: Agamben contra Nietzsche
}

Répétitions is the name that Paul Eluard gives to one of his collections of poetry, for whose frontispiece Max Ernst has drawn four small boys. They turn their backs to the reader, to their teacher and his desk as well, and look out over a balustrade where a balloon hangs in the air. A giant pencil rests on the windowsill. The repetition of childhood experience gives us pause: when we were little, there was as yet no agonized protest against the world of our parents. As children in the midst of the world, we showed ourselves superior. When we reach for the banal, we take hold of the good along with it — the good that is there (open your eyes) right before you. -Walter Benjamin, Dream Kitsch (1927)

In his 1988 foreword to Infancy and History: The Destruction of Experience, Giorgio Agamben declares, "In both my written and unwritten books, I have stubbornly pursued only one train of thought: what is the meaning of 'there is language'; what is the meaning of 'I speak'?" (Agamben 2007, 6). There is no cause to doubt the philosopher's word, when from infancy to testimony, his work across the decades indicates a clear engagement with the enunciative. But, what of that other facet of language, the inscriptive - that is, what of writing? In a radio interview that the philosopher gave in 2004 , he commented that "wanting to write is the desire to experience potentiality" (Durantaye, 2-3).

Agamben's disposition toward writing, however, is more ambiguous than this sentiment may suggest, as is indicated by his sometimes emphatic and sometimes ambiguous stance on Friedrich Nietzsche's eternal recurrence of the same, to which he has sometimes referred in relation to the inscriptive. For instance, in a passing remark at the end of another interview that 
he gave to the Süddeutsche Zeitung in that same year, Agamben commented that he stands "with Benjamin, who said, the eternal return is like the punishment of detention, the sentence in school in which one had to copy the same sentence a thousand times" (Raulff, 614). Compare this assessment of the eternal return to that in his 1982 essay titled "Benjamin and the Demonic: Happiness and Historical Redemption.” Therein, by contrast, Agamben qualifies Benjamin’s reading of the eternal return that "perhaps unjustly" sees in it "the punishment given to schoolchildren that consists in having to copy out the same text countless times," by noting the German-Jewish thinker's recognition of its revolutionary possibility for "[exasperating] mythic repetition to the point of finally bringing it to a halt" (Agamben 1999b, 155).

Nevertheless, Agamben elsewhere addresses the eternal return with no apparent reference to writing, as in its mention in "Marginal Notes on Commentaries on the Society of the Spectacle" (1990) in which he cites it as an example of "the messianic shift that integrally changes the world, leaving it, at the same time, almost intact ..." (Agamben 2000, 79), while in Remnants of Auschwitz: The Witness and the Archive (1998), it shares its temporal status with the camp (Agamben 1999c, 99-103). These are but a few of the varied references to the eternal return in his corpus that range from affirmative to condemnatory.

What precisely is at stake here? Is Agamben's fluctuating position on the eternal return simply a matter of "a move away from the line drawn by one treasured thinker in the direction of a line drawn by another," in the difficult endeavor of "developing a philosophy of potentiality able to come to terms with the past," as one critic has argued (Durantaye, 323)? ${ }^{\mathrm{i}}$ Is the Strafe des Nachsitzens, the punishment of writing lines that Benjamin refers to, thus merely an expedient analogy rather than an indicator of the particularity of writing to Agamben's determination of Nietzsche's concept? Even if one were to accept the hypothesis that in Remnants of Auschwitz 
Agamben rereads the eternal return as incompatible with his concern for the past, is the account of his profound change in position as simply coterminous with the influence of other thinkers adequate to the task of drawing out this thought from obscurity? To the contrary, beyond the register of potentiality, Agamben's shift in position on Nietzsche's eternal return, when read in its own specificity, betrays an affinity between writing and instrumentality in which temporality plays a crucial role.

The philosopher's engagement with the eternal return begins with a somewhat distant set of concerns, however, bearing the inflection of his teacher Martin Heidegger. In his 1970 treatise on art and the history of aesthetics, The Man Without Content, Agamben's affirmative reading of the eternal return strongly echoes Heidegger's four-volume Nietzsche (1961), with its emphasis on both inversion and the decisive character of surpassing nihilism. ${ }^{\text {ii }}$ In this early encounter with Nietzsche, Agamben reads in the eternal return the ultimate inversion of nihilism that man achieves in art, his "highest task and truly metaphysical activity." He writes, "In the idea of the eternal recurrence, nihilism attains its most extreme form, but for precisely this reason it enters a zone in which surpassing it becomes possible" (Agamben 1999a, 87-8).

In Man Without Content, Agamben distinguishes between the passive Romantic nihilism that impoverishes life and the vital enrichment of an active Dionysian nihilism to propose the thought of an art that, detached from all historical conceptions of aesthetics founded upon ideas of spectatorship and creative genius, joins the will to power and the eternal return in a circle in which the three reciprocally "belong to one another" (89-90). Determining the will to power as the most intimate essence of being as life and becoming, and the eternal return as "the most extreme possible approximation of a world of becoming to a world of being," Agamben argues that it is in art, as the fundamental trait of the will to power, that "the essence of man and the 
essence of the universal becoming are identical to one another" (92; translation modified). Citing Nietzsche's aphorism “The Heaviest Weight” of The Gay Science (1882) in which the demon condemns one to relive every moment of his life identically over and over for eternity (Nietzsche 273-4), through his participation in art, man's will to power grasps and inhabits this curse, inverting the nihilism of the eternal recurrence of the same into the amor fati that loves and desires just this. With a messianic inflection, Agamben avers, "Nihilism is surpassed in the man who recognizes his essence starting from this will and this love, and who tunes his being to the universal becoming in the circle of the eternal recurrence. At the same time, chaos and nature are the object of a redemption that transforms every 'it was' into 'thus I wanted it to be'" (Agamben 1999a, 91).

A number of years later in 1986, Agamben again addressed the subject of the eternal return and its affiliation to the will to power in a paper titled "The Eternal Return and the Paradox of Passion." This essay, though still bearing traces of the influence of Heidegger, touches upon a number of concepts found elsewhere in Agamben's oeuvre, and already evidences a more nuanced perspective on Nietzsche's proposition. Determining the same (gleiche) of the eternal return of the same (ewige Wiederkehr des Gleichen), as likeness or image via an elaborate etymological lineage inclusive of the term corpse, he writes,

The paradox that Nietzsche invites us to consider is that of an Abbild, an image which precedes both what it is an image of, and what it is impressed upon: a like, a likeness which anticipates both terms being compared, being likened. Not only, therefore, does the thought of eternal return contain a like, an image, but this like, this image, is the Original, preceding both being and becoming, both the subject and the object. But how can an image precede that of which it is an image? How can we 
conceive of a likeness, an omoisis, which precedes that to which it bears resemblance? How can the impression be more primordial than the subject which bears it? ... . The image in question is not an image of nothing. It is perfectly selfreferential. The [will to power] is a [will to likeness] to a pure likening involving neither subject nor object - an image of itself, the impression of itself on itself, pure self-affection (Agamben 1988, 14).

While Agamben's formula to some extent recalls Heidegger's imagining of the will to power as a will to semblance (Heidegger, 218), ${ }^{\text {iii }}$ the agency associated with art in Man Without Content as the "truly metaphysical activity of man" is absent from this construction as the like- the image - becomes the autonomous Original that precedes that of which it is an image. As pure likening, it assumes the mediatory status of his later formulation of pure means as communicability (Agamben 2000, 56-60), but here as an originary capacity for transmission that comes before all else, any act or representation.

The self-referential image of the will to likeness [Wille zur Gleichheit], as an originary impressibility, is not an emptiness but a potency that is both active and passive, in his words, both a passive receptivity and a tension towards action and spontaneity (Agamben 1988, 15) that extends beyond the imagistic to the implicate the inscriptive as well. Reflecting upon its kinship with a late fragment of Kant's on the thing-in-itself and Aristotle's On the Soul, he likens this potency that unites in itself passivity and spontaneity, potentia and act, to a wax surface upon which nothing is written, an "inextinguishable potency” (Agamben 1988, 16).

While Agamben will later embrace the uninscribed writing tablet in the name of potentiality, here, evoking Klossowski, he understands the "vicious circle" of Nietzsche's will to likeness as a mere reiteration of the paradox of the fundamental precept of Western philosophy, 
"the bottomless foundation of pure subjectivity in pure self-affection" (15). ${ }^{\text {iv }}$ However, unlike Bataille and Levinas, whom he claims that along with Derrida and Heidegger have all pushed just such a passivity to its extreme pole in the attempt to extricate potentia passiva from the knot that binds it to potentia activa, Agamben asserts that Nietzsche's effort to surpass the wax tablet with the eternal return in fact comprises the conception of a "final identity" of the two powers, active and passive, coinciding in the will to power as a pure passion affecting itself (17).

In words foreshadowing those employed in Remnants of Auschwitz: The Witness and the Archive (1998) to a very different end, Agamben writes,

Pure passion, as the final coincidence of potentia passiva and potentia activa, is in itself immemorable. The like, the image perpetually returning, cannot be retained in the memory. Its eternal return is its passion, in which, between the writing and its erasing, there is, as Nietzsche says, keine Zeit, no time. . . As an image of nothing, the like disappears in its own enduring, and is destroyed through its own salvation (17).

Contrary to his later insistence in Remnants of Auschwitz upon the impossible coincidence of these two facets of subjectivity (Agamben 1999c, 109-12), the overriding sense here in which between writing and its erasing there is no time, there seems to be not some eternally primordial before nor a fleeting time that cannot be grasped, but rather a compression of time-a complete and total coincidence that disintegrates into timelessness, as active and passive are fused into a single originary power. ${ }^{\mathrm{v}}$ The eternal return thus does not linger in a before writing, "a 'passionate' dimension which precedes all possibility and in which nothing has yet been given to Dasein" (Agamben 1988, 17). Rather, in the eternal return the active and passive principles are conjoined with no remainder, no time. "The Eternal Return and the Paradox of Passion" thus 
stakes a claim for Nietzsche's proposition that Agamben will retain in Remnants of Auschwitz, but unequivocally distance himself from.

Between these two early mentions of the eternal return, one can determine a clear line of influence leading to its appearance in Agamben's essays on gesture of the early 1990s that feature in the Means Without End volume, though the emphases of the latter tend toward the imagistic and the enunciative, rather than the inscriptive. With its insistence upon the fusion of potential and act that produces a liberating force from a vacuous present, the earlier of the two, "Marginal Notes on Commentaries on the Society of the Spectacle" (1990), bears a somewhat more direct if esoteric relationship to Man Without Content and the "Paradox of Passion" essay than "Notes on Gesture" (1992).

Commenting upon the transformative force of Debord's situation, Agamben asserts, The situation is neither the becoming-art of life nor the becoming-life of art. We can comprehend its true nature only if we locate it historically in its proper place: that is, after the end and self-destruction of art, and after the passage of life through the trial of nihilism. The "Northwest passage of the geography of the true life" is a point of indifference between life and art, where both undergo a decisive metamorphosis simultaneously. This point of indifference constitutes a politics that is finally adequate to its tasks. The Situationists counteract capitalism—which "concretely and “deliberately" organizes environments and events in order to depotentiate life-with a concrete, although opposite, project. Their utopia is, once again, perfectly topical because it locates itself in the taking-place of what it wants to overthrow (Agamben 2000, 78-9). 
Thus, at the fated historical moment after the end of art, an inhabitation of the medial takingplace may invert the depotentiated life produced by capitalism into a liberated concrete presence. $^{\mathrm{vi}}$ Referring once more to The Gay Science, Agamben cites the eternal return as the exemplary situation:

A constructed situation is the room with the spider and the moonlight between the branches exactly in the moment when — in an answer to the demon's question: "Do you desire this once more and innumerable times more?"—it is said: "Yes, I do." What is decisive here is the messianic shift that integrally changes the world, leaving it, at the same time, almost intact: everything here, in fact, stayed the same, but lost its identity (79).

Recalling the "Paradox of Passion" essay's eternal return of the like that is "destroyed through its own salvation," the messianic shift of the eternal return here evacuates identity, but does so by exploiting the mediatory "point of indifference" of gesture. Despite its language of the messianic, Agamben's sentiment echoes not just Klossowski, but also Deleuze who himself draws much from the latter. The critique of representation implicit here recalls that of Difference and Repetition (1968), in which repetition in the eternal return "carries every object to that extreme 'form' in which its representation comes undone," the affirmation of a world that is both completed and without limit (Deleuze 2011, 69). ${ }^{\text {vii }}$

This messianic potency of the eternal return recurs in "Notes on Gesture" (1992), though it is somewhat compromised by its location within a more intricate framework of time and history. Assigning Nietzsche's historical site at the culmination of European culture's crisis of gesture that would see it either lost or transfigured into fate, Agamben avers, "The thought of the eternal return, in fact, is intelligible only as a gesture in which potential and act, naturalness and manner, 
contingency and necessity, become indiscernible (ultimately, in other words, only as theatre)" (Agamben 2000, 53; translation modified). Amor fati thus represents here the last gasp of the wish of a humankind already bereft of gestures to cleave to them.

In a marked departure from the "Paradox of Passion" essay, the eternal return of the same as image gives way to the eternal return as gesture, and Agamben here sets the two in opposition. Taking a cue from Deleuze's work on cinema, the gesture as the "exhibition of a mediality" figures the messianic inversion that shatters the mythical rigidity of the image. The dichotomy between the image and gesture repeats the terms of the "Paradox of Passion" essay, but to different effect. While in the first instance, the imago founds the like of the eternal return, here it represents its opposite as the effacement of the gesture:

Every image, in fact, is animated by an antinomic polarity: on the one hand, images are the reification and obliteration of a gesture (it is the imago as death mask or as symbol); on the other hand, they preserve the dynamis in tact (as in Muybridge's snapshots or in any sports photograph). The former corresponds to the recollection seized by voluntary memory, while the latter corresponds to the image flashing up in the epiphany of involuntary memory. And while the former lives in magical isolation, the latter always refers beyond itself to a whole of which it is a part (55).

Despite the Deleuzian character to these readings of the eternal return, consistent with his thought in the early to mid-1990s, this turn of phrase with which Agamben establishes a correspondence between will and temporality, is suggestive of sentiments expressed elsewhere on the Platonic Idea. The potency of the gesture emerges unexpectedly and fleetingly, while the reification of gesture in the image conveys a stagnation in an impossible willed time. In "Notes on Gesture," Agamben expands upon the relationship of the gesture with the Idea: 
A paralyzing power whose spell we need to break, is continuously at work in every image; it is as if a silent invocation calling for the liberation of the image into gesture arose from the entire history of art. This is what in ancient Greece was expressed by the legends in which statues break the ties holding them and begin to move. But this is also the intention that philosophy entrusts to the idea, which is not at all an immovable archetype as common interpretations would have it, but rather a constellation in which phenomena arrange themselves in a gesture (56).

This opposition between image and gesture further disrupts Agamben's conception of the eternal return itself as presented in the "Paradox of Passion" essay by shifting its characterization as the potent emptiness of an image that always precedes itself to the fullness invited by gesture that always refers beyond itself to the whole of which it is a part.

While the suggestion of the Platonic Idea may seem quite distant from Nietzsche and the eternal return, the opposition that Agamben stages here between the gesture and the static image recalls an earlier argument that discloses an antipathy for writing embedded within the philosopher's opposition between the Platonic and Aristotelian theories of language. Whereas in the concluding sentiment of "Notes on Gesture," the appearance of the Idea in the gesture is stated as the exposure of a word in "its own mediality," a "communication of a communicability" (59), in the 1984 essay that he dedicated to Jacques Derrida, "The Thing Itself," Agamben asserts that the task of philosophical presentation is the "coming of speech to speech" (Agamben 1999b, 33-4). This task is accomplished by casting off the Aristotelian prote ousia that is characterized by a negative temporality and impossible presence residing in the gramma, and restoring to language its sayability, the Platonic thing itself in the Idea characterized by the absolute present of pure communicability. 
In order to place Agamben's position on the eternal return within the parallel development of language in his thought, it is a worthy digression to consider this essay, included in the Potentialities compilation, and briefly rehearse its opposition between the thing itself of the Platonic Idea with the Aristotelian prote ousia. In “The Thing Itself,” Agamben finds in Plato's discussion of the five aspects of the Idea [Letter VII 342a-343a] (Plato, 1589-90) a theory of linguistic signification that acknowledges the sayability that is unsaid and forgotten in the saying. This is the fifth aspect that illuminates the other four, the thing itself that founds the weakness of language, the restitution of which is Agamben's imperative (Agamben 1999b, 33-5).

Where Aristotle diverges from this Platonic construction is with his three-fold theory of signification delineated in the opening lines of On Interpretation [16a2-8] (Aristotle Vol. 1, 25) that in effect eliminates the fourth and the fifth aspects: knowledge and the thing itself. In this Aristotelian model, which, according to Agamben, is shared by the modern distinction between sense and denotation, the sayability of the thing itself is subsumed as the presupposition that makes predication operative through the order of the gramma. As Agamben explains, within this construction "Language is thus always ... saying something-on-something; it is therefore always pre-sup-positional and objectifying language. Presupposition is the form of linguistic signification ... speaking about a subject” (Agamben 1999b, 33).

While the thing itself has been apparently suppressed by Aristotle, its replacement emerges in his Categories in the form of the protē ousia [2a12-4b19] (Aristotle Vol. 1, 4-8). Agamben argues that the protē ousia, a concept that he had prior named as a negative metaphysical operator in Language and Death: The Place of Negativity (1982) (Agamben 1991, 16-8), significantly modifies the temporality of language in acquiescence to the demands of writing: 
Expelling the thing itself from his theory of signification, Aristotle absolves writing of its weakness. In the place of the thing itself, in the Categories there appears prote ousia, first substance, which Aristotle defines as that which is said neither about a subject (kat' hypokeimenou, by means of presupposition) nor in a subject. What does this definition mean? First substance is not said on the basis of a presupposition; it does not have presuppositions, because it is itself the absolute presupposition on which all discourse and knowledge are founded. It alone — as name — can be said kat'auto, by itself; it alone — not being in a subject—clearly shows itself. But in itself, as individuum, it is ineffable . . . and cannot enter into the linguistic signification that it founds, except by abandoning its status as deixis and becoming universal predication. The "what," ti, that was at issue in the name is subsumed into discourse as a kata tinos, "that about which" something is said. They-both the what and the about which - are therefore the same thing, which can be grasped as to ti en einai, the Being-the-what-that-was. In this logico-temporal process, the Platonic thing itself is removed and conserved or, rather, conserved only in being removed: eliminated (Agamben 1999b, 37).

According to Agamben, Plato's unsayable sayabilty - the "weakness of language" that can never be inscribed-is transmuted into writing in Aristotle's thought. In the process, it is spectralized as the ultimate ineffable presupposition of predication itself through its transposition into a temporal structure. In this conflation or flattening of deixis into predication, sayability is separated from the linguistic act and relegated to the threshold of language where it is held in what, though predating the terminology of Homo Sacer: Sovereign Power and Bare Life (1995) by a decade, can be described as an inclusive exclusion. What was a contemporaneity in Plato is 
now circumscribed by a negative temporality induced by writing. Sayability becomes

predication, captured in representation and obstructed by time, never arriving to speech, as the presence of the thing itself is forever consigned to the past tense in writing, from the what to the about which.

This passage is rich with affinities to the philosopher's other work on language, but as it pertains to this critical inquiry, one can discern in this opposition between the prote ousia and the thing itself the argument that he adopts in the "Paradox of Passion" essay. While the "perfectly self-referential" image, the "Original," of the eternal return of the like seems to share the autonomy that comes with an absence of subject or object with the prote ousia as "the absolute presupposition on which all discourse and knowledge are founded," with the eternal return Agamben attempts to overcome the prote ousia's temporal confinement in the past of predication by confounding the presence/absence binary.

Indeed, the latent tension here, which implicates will no less than time, extends well beyond "The Thing Itself," treading the same conceptual terrain as the eternal return. This tendency is evident in Man Without Content as well as the "Paradox of Passion" essay; but, it is in "Notes on Gesture" that Agamben explicitly attempts to fuse together the decisive affirmation of Nietzsche's eternal return with the adventitiousness of the Platonic Idea in such a way that the temporal considerations that he attributes to each stand in contradiction. The eternal return is an inversion of the nihilism presiding over a distended temporality that simply reappropriates power, while the Platonic Idea is the rupture of this distended temporality as the gesture "flashes up in the epiphany of involuntary memory." In the first instance, there is an expression of will, in the second precisely not. In both cases, the liberating force of transmissibility is situated in a 
liminal position, but it is alternatively an absence of meaning to be loved and a presence of meaning to be recognized.

Throughout these references to Nietzsche, impressions of Benjamin emerge periodically in Agamben's argumentation. His discussions of gesture are at times reminiscent of Benjamin's discussion of the Platonic Idea in the "Epistemo-critical Prologue" of his The Origin of German Tragic Drama (1928) (Benjamin 1998, 31-8), and in the "Paradox of Passion" essay Agamben even refers in passing to the eternal return as a "dialectical image" (Agamben 1988, 10). ${ }^{\text {viii }}$ Benjamin's own engagement with the eternal return, as it appears in various fragments in his incomplete Arcades Project (1982) and notes toward the related unfinished work Charles Baudelaire: A Lyric Poet in the Era of High Capitalism, ${ }^{\mathrm{ix}}$ is complex and unresolved. While this may play some part in Agamben's own shifting disposition toward Nietzsche's idea, among Benjamin's discontinuous articulations there is a consistency in his identification of a conceptual triad between Nietzsche, Baudelaire and the nineteenth-century revolutionary socialist Auguste Blanqui. In a letter to Max Horkheimer dating from the spring of 1938, he speaks of the "idée fixe of the new and the immutable" that unites the three thinkers (Benjamin 1994, 557), a thought that is iterated in numerous other passages.

It is Blanqui's final work Eternity by the Stars (1872), written while he was imprisoned, that Benjamin cites most frequently for its affinity to the eternal return. In this work, published ten years prior to The Gay Science, Blanqui proposes a cosmological theory in which the universe is comprised of only one hundred elemental bodies that are repeated infinitely, implicating both astral systems and earthly life. A letter to Horkheimer of the same year provides an early formulation of the relevance of Blanqui to Benjamin's project on nineteenth-century modernity: 
While deriving his data from mechanistic natural science, the worldview that Blanqui outlines is in fact an infernal view, and is, at the same time, in the form of a natural view, the complement to a social order that Blanqui had to recognize as victorious over him in the last years of his life. . . It represents unconditional submission, but at the same time the most terrible accusation against a society that has reflected this image of the cosmos as a projection of itself on to the heavens (Benjamin 1994, 549). Interestingly, it is precisely this assessment of Blanqui's thought that Agamben cites in the 1982 essay "Benjamin and the Demonic" in regard to the eternal return, which he also likens to the punishment given to schoolchildren of writing lines, the Strafe des Nachsitzens (Agamben 1999b, 155). Indeed, writing is among the images that Blanqui conjures and Benjamin in turn transposes in his incomplete drafts of the book on Baudelaire and The Arcades Project: "What I write at this moment in a cell at the Fort du Taureau I have written and shall write throughout all eternity — at a table, with a pen, clothed as I am now, in circumstances like these. And thus it is for everyone" (Blanqui, 146; cited in Benjamin 2002, 114). Benjamin himself alludes to the Strafe des Nachsitzens in The Arcades Project in regard to Blanqui's theory as one of a mythical repetition that implicated a humanity who in each century is kept in after school (118).

The ambivalence on the eternal return that Agamben espouses in his 1982 essay can thus without much difficulty be reconstructed in its source material, in spite of — or perhaps due tothe profusion of references across copious drafts produced over the span of more than a decade in which Benjamin reworked these ideas in numerous variations. On the one hand Blanqui's theory is exemplary of his century's ideological espousal of myth; but, on the other hand, it is this ideological locus of the transposition of the immutable onto the new that must be the site of its own redemption. As Benjamin muses, "Blanqui, who, on the threshold of the grave, 
recognizes the Fort du Taureau as his last place of captivity, writes this book in order to open new doors in his dungeon" (111). ${ }^{\mathrm{x}}$

Notwithstanding, while in Benjamin's thought the proximity of the exercise of writing to Nietzsche is not so fixedly determined, it is precisely the image of the writing desk that Agamben evokes to stake a claim for a thought beyond Nietzsche, severing the Benjaminian nexus between the eternal return and Blanqui's astral eternity in the process. This move takes place in his essay "Bartleby, or On Contingency" of 1993, originally published in a volume with Deleuze's "Bartleby, or the Formula" of the same year, in which he makes a case for the contingent, a concept that will resonate in his later philosophy. In this text, Agamben argues that whereas in the thought of Blanqui one may still discern a faint lament for "what was not or could have been otherwise," Nietzsche's eternal return consigns potential being to the past. He also returns to Benjamin's reading of Nietzsche here and, despite the former's own conceptualization of Blanqui in relation to the Strafe des Nachsitzens, Agamben instead deploys this metaphor to differentiate the two thinkers, ascribing Nietzsche's eternal return to the punishment of the child writing lines, condemned to copying out the texts of humanity innumerable times, wholly absent of any revolutionary value in its mythic repetition (Agamben 1999b, 268). The eternal return is thus guilty of suppressing the contingent, which is to become the constitution of the subject in Remnants of Auschwitz.

Furthermore, in "Bartleby" Agamben embraces the wax tablet that he formerly passed over in the "Paradox of Passion" essay, now favoring the extreme passivity that he there imputes to Bataille, Derrida, Levinas and Nancy. Whereas once it was Nietzsche's elimination of time between writing and erasing that surpassed the paradox of passion of Aristotle's writing tablet in its fusion of the will to power and pure receptivity that captivated Agamben (Agamben 1988, 14- 
7), here the personage of Bartleby, Melville's reluctant scrivener that becomes himself a writing tablet_- "his own white sheet"- is the figure of salvation (Agamben 1999b, 253-5). With his preference "not to" that introduces contingency into the scheme of potentiality, which Agamben notes has frequently reduced to merely will and necessity, Bartleby becomes the very personification of contingency. He writes,

To be capable, in pure potentiality, to bear the "no more than" beyond Being and Nothing, fully experiencing the impotent possibility that exceeds both-this is the trial that Bartleby announces. The green screen that isolates his desk traces the borders of an experimental laboratory in which potentiality, three decades before Nietzsche and in a sense altogether different from his, frees itself of the principle of reason. Emancipating itself from Being and non-Being alike, potentiality thus creates its own ontology (259).

The Benjaminian writing desk of Blanqui, at which he forges new doors to his dungeon, becomes both the site of Nietzsche's eternal punishment of writing lines and the messianic potentiality of Bartleby's cessation of writing.

Potentiality, in the Agambenian sense, is thus opposed to the eternal return with reference to writing. While in the endless copying of the eternal return, "the infinite repetition of what was abandons all its potential not to be," the interruption of writing when the scrivener stops copying provokes a messianic moment of "decreation" in which "God summons all his potential not to be, creating on the basis of a point of indifference between potentiality and impotentiality" (268, 270). Agamben continues, "The creation that is now fulfilled is neither a re-creation nor an eternal repetition; it is, rather, a decreation in which what happened and what did not happen are returned to their originary unity in the mind of God, while what could have not been but was 
becomes indistinguishable from what would have been but was not" (270). Here, the eternal return, rather than being itself a messianic force as encountered in the gesture essays, instead appears as an obstacle to messianic force whose unrelenting repetition must cease.

In addition to this aversion toward writing that is shared with "The Thing Itself," Agamben's critique of the eternal return here largely hinges upon questions of will and decision. Bartleby's signature "I'd prefer not to" opens a "zone of indistinction" between yes and no and thus confounds the common misguided attribution of decision to potentiality and its relation to actuality. He explains, "Potentiality is not will, and impotentiality is not necessity; . . . To believe that will has power over potentiality, that the passage to actuality is the result of a decision that puts an end to the ambiguity of potentiality (which is always potentiality to do and not to do)this is the perpetual illusion of morality" (254-5). This illusion mirrors that of the sovereign decision that is always in the position of an undecidable, yet it is opposed to the pure force of the self-reflexive, self-perpetuating will in Language and Death (Agamben 1998, 27; 1991, 86-7).

Further bolstering the critique of instrumentality that may readily be discerned in Bartleby's impotence, reason joins will and decision in its undoing by the scrivener's quiet espousal of preference and potentiality, both of which "no longer function to assure the supremacy of Being over Nothing," but rather exist in the indifference between the two. Interestingly, Agamben argues that this indifference does not constitute an equivalence between these two opposite principles (Agamben 1999b, 259). Potentiality instead "creates its own ontology" in a liminal state of senselessness and indecision. Unlike the eternal return which is nothing more than a "will to will" of "an eternally repeated action," a fallacy that is captive of the nihilism it purports to embrace, Bartleby's cessation of copying —of will, reason and decision - ultimately bears upon the relation of humanity to the law, instituting "a liberation 
from the "oldness of the letter"' $(268,270)$. Notwithstanding his bleak end, Bartleby, assumes the figure of the Messiah. ${ }^{\mathrm{xi}}$

Where Agamben makes a final break from his various earlier exegeses and definitively condemns the eternal return is in Remnants of Auschwitz. Here, his critique of Nietzsche's proposition, previously aligned with pure means, is intimately bound up with temporality and the metaphysics of presence. In this seminal text, the eternal return not only marks the failure of the twentieth-century ethical project to overcome resentment, it also represents the disaster of the attempt to conceptualise an authentic originary temporality.

Comparing Primo Levi's The Drowned and the Saved (1986) to Jean Améry's At the Mind's Limits: Contemplations by a Survivor on Auschwitz and Its Realities (1964), Agamben attributes to each a particular invalidation of the eternal return:

The ethics of the twentieth century opens with Nietzsche's overcoming of resentment. Against the impotence of the will with respect to the past, against the spirit of revenge for what has irrevocably taken place and can no longer be willed, Zarathustra teaches men to will backward, to desire that everything repeat itself. The critique of Judeo-Christian morality is completed in our century in the name of a capacity fully to assume the past, liberating oneself once and for all of guilt and bad conscience. The eternal return is above all a victory over resentment, the possibility of willing what has taken place, transforming every "it was" into a "thus I wanted it to be"-amor fati (Agamben 1999c, 99).

In light of Auschwitz, which one could never wish to relive, the response to the demon's provocation to renounce resentment, "Do you desire this once more and innumerable times more?" is not only an absolute refusal of the amor fati, and a cleaving to resentment to hold the 
truth of the atrocity before the criminal as advocated by Améry. The eternal return is, in the end, redundant in the face of the "ferocious and implacable experience" of Levi's recurring nightmare of Auschwitz: "One cannot want Auschwitz to return for eternity, since in truth it has never ceased to take place; it is always already repeating itself' (100-1). While the eternal return exemplifies the failure of ethics in its futile attempt to surpass morality, it also shares with the horror of Auschwitz "a new, unprecedented ontological consistency" in the way of its distinctive temporal status.

The experience of Auschwitz eternally returns not only in dreams, but also as prophetic certainty. Past and future collapse as their temporal boundaries dissolve. Speaking of the altered character of the ethical problem after Auschwitz, Agamben asserts,

It is no longer a question of conquering the spirit of revenge in order to assume the past, willing its return for eternity; nor is it a matter of a holding fast to the unacceptable through resentment. What lies before us now is a being beyond acceptance and refusal, beyond the eternal past and the eternal present - an event that returns eternally but that, precisely for this reason, is absolutely, eternally unassumable. Beyond good and evil lies not the innocence of becoming but, rather, a shame that is not only without guilt but even without time (102-3).

In terms identical to those of the "Paradox of Passion" essay, Agamben articulates the unique capacity of the camp to obliterate human subjectivity through its distension of time. The absence of time between writing and its erasure imagined there, here undertakes not only the surpassing of metaphysics but the eradication of the human being as well. Shame, which Agamben establishes as the temporal constitution of the human subject (109-12), is here stripped of its time. In this timeless space of the camp, his earlier conclusion to the "Paradox of Passion" essay 
resonates in a darker tone: "Pure passion, as the final coincidence of potentia passiva_and potentia activa, is in itself immemorable. The like, the image perpetually returning, cannot be retained in the memory. Its eternal return is passion, in which, between the writing and its erasing, there is, as Nietzsche says, keine Zeit, no time” (Agamben 1988, 17). Agamben's etymology of the like of the eternal return as cadaver (9) becomes the camp's fabrication of corpses (Agamben 1999c, 70-2).

In Remnants of Auschwitz, the condition of the camp as a spatio-temporal entity now implicates the eternal return and invalidates any conception of an originary temporality in which "the 'I' comes to itself in authentically assuming its own irreparable past" (127). The truly metaphysical activity of the Man Without Content to "[tune] his being to the universal becoming in the circle of the eternal recurrence" (Agamben 1999a, 91) is far removed from Remnants of Auschwitz, and the futility attributed to its "will to will" in "Bartleby" (Agamben 1999b, 268) assumes the status of the worst. He writes, "The camp, the absolute situation, is the end of every possibility of an originary temporality, that is, of the temporal foundation of a singular position in space, of a $D a$. In the camp, the irreparability of the past takes the form of an absolute immanence; ... anticipation and succession are parodically flattened on each other" (Agamben 1999c, 128). This flattening equates the displacement of contingency with the forced existence of the impossible, the catastrophe of the subject that "defines a biopolitical experiment on the operators of Being, an experiment that transforms and disarticulates the subject to a limit point in which the link between subjectification and desubjectification seems to break apart" (148).

Agamben's response to this temporal crisis in which past and future, life and law, possible and impossible, coincide in an interminable non-moment is not the inversion encountered in the Means Without End essays - this would simply rehearse the will to will—-nor is it the 
expropriation from language all reference through a Bartleby-like decreation instituting of zone of indistinction between potentiality and impotentiality (Agamben 1999b, 255, 270) which would, rather than instantiating contingency, see it eradicated. Agamben's thought here instead indicates an alternative consideration given to time. He states,

We must cease to look toward processes of subjectification and desubjectification, of the living being's becoming speaking and of the speaking being's becoming living and, more generally, toward historical processes as if they had an apocalyptic or profane telos in which the living being and the speaking being, the inhuman and the human—or any terms of a historical process — are joined in an established, completed humanity and reconciled in a realized identity. This does not mean that, in lacking an end, they are condemned to meaningless, disenchanted drifting. They have not an end, but a remnant. There is no foundation in or beneath them; rather, at their center lies an irreducible disjunction in which each term, stepping forth in the place of a remnant, can bear witness (Agamben 1999c, 159).

In this passage, the liminality that in his earlier work was so characterized by indeterminacy is now reconceived as an irreducible disjunction that stands in contrast to a "meaningless, disenchanted drifting," a phrase evocative of Agamben's persistent criticisms of Derrida.

Indeed, though in Remnants of Auschwitz, Agamben does not refer directly to writing in relation to the eternal return or in the familiar idiom of the Strafe des Nachsitzens, the inscriptive is nonetheless implicated as it appears within the figure of deconstruction. Like his determination of the eternal return, deconstruction here exhibits the temporality of the camp. While Agamben conceives the enunciative construct of testimony as taking place in the irreducible disjunction of bearing witness, "the subject's only dwelling place," it is in this very "non-place" that 
deconstruction instead 'inscribes its 'trace' and its différance, in which voice and letter, meaning and presence are infinitely differed." He continues, "The intimacy that betrays our noncoincidence with ourselves is the place of testimony. Testimony takes place in the non-place of articulation. In the non-place of the Voice stands not writing, but the witness" (129-30).

Deconstruction's infinite deferral of signification in writing is thus summarily dismissed in favour of the mechanistic alterity of testimony. ${ }^{\text {xii }}$ Rather than the interminable coincidence of sense and denotation of deconstruction (Agamben 1998, 25) or that of past and future of the eternal return with which it shares a disposition toward writing, in testimony the currents of subjectification and desubjectification are described as "coextensive, but not coincident." With this swapping of terms, Agamben reinserts spatial and temporal boundaries into the camp's spatio-temporal conflation of the threshold of subjectivity. He writes,

The human being is thus always beyond and before the human, the central threshold through which pass currents of the human and the inhuman, subjectification and desubjectification, the living being's becoming speaking and the logos' becoming living. These currents are coextensive, but not coincident; their non-coincidence, the subtle ridge that divides them, is the place of testimony (Agamben 1999c, 135).

The eternal return, as the final coincidence of active and passive principles is timeless, while the noncoincidence of the active and passive principles of the subject produced in the temporality of auto-affection has time as its only preserve against obliteration. Testimony is the subject's sole respite from the absolute immanence of the camp that eternally returns.

In a late fragment titled "New Theses C" Walter Benjamin writes, "The fundamental concept of myth is the world as punishment - punishment which actually engenders those to whom the punishment is due. Eternal recurrence is the punishment of being kept in after school, 
projected onto the cosmic sphere: humanity has to copy out its text in endless repetitions (Eluard, Répétitions)" (Benjamin 2006, 403; translation modified). In light of Benjamin's earlier reference to Répétitions and Max Ernst's frontispiece of the four boys distracted by a horizon beyond their detention, the place of eternal recurrence in his schema of redemption remains ambiguous. This is not so for Agamben, in whose thought the eternal return traverses a spectrum from the redemptive to the annihilative. Furthermore, it is clear that not only has the philosopher's reading of Nietzsche changed, but so have those of Benjamin and Heidegger, both of whom have had a profound influence on his thought.

What emerges through Agamben's extensive engagement with Nietzsche's proposition is an instrumental conception of the inscriptive that shares its temporal catastrophe. This constellation bears ongoing relevance in Agamben's thought. Consider his citation in The Signature of All Things: On Method (2008) of the Roman Curia's suppression of the monks' form of life with its codification of the regula in writing (Agamben 2009, 21-2), a question elaborated in The Highest Poverty: Monastic Rules and Form-of-Life (2011) in which law and writing become synonymous (Agamben 2013, 86-8). This line of enquiry is particularly salient in light of the imminent conclusion of the Homo Sacer series in which Agamben completes his ontology of politics. 
Notes

in his exhaustively researched critical introduction, Leland de la Durantaye both accuses
Agamben of misrepresenting Nietzsche's idea of the eternal return in Remnants of Auschwitz on
the subject of overcoming resentment ("Here it is as if Agamben were responding to a vulgarized

ii So pronounced is Heidegger's influence upon his reading of Nietzsche in this text that Agamben explicitly acknowledges his debt to the philosopher in a footnote, citing the impossibility of the chapter's presentation of Marx without his teacher's studies of Nietzsche. (Agamben 1999a, 127 n.32). Indeed, the correspondences of Agamben's reading here with Heidegger's are too abundant to enumerate.

iii Crucially, Heidegger's formula is founded on the term Schein rather than Gleichen (Heidegger 214). While Agamben does note Nietzsche's assertion of the will to power as a will to Schein, he does not give mention to Heidegger and furthermore treats the two formulae as synonymous: '[Nietzsche] is therefore able to write that 'the will to likeness is the will to power' as elsewhere he had stated that the will to power is the will to Schein, to appearance and becoming" (Agamben 1988, 13).

iv See Klossowski's discussion of the symbiotic relation between active and passive in the eternal return in Nietzsche and the Vicious Circle (Klossowski 1997, 98-9). Interestingly, there is also a discernable affinity here in Agamben's characterization of the image that "precedes both what it is an image of and what it is impressed upon" and Maurice Blanchot's commentary on Klossowski's thought of the image that "must cease to be second in relation to an alleged first object and must lay claim to a certain primacy, just as the original and finally the origin will lose their privileges as initial powers." This passage is quoted by Deleuze in a footnote of Difference 
and Repetition. See Blanchot's "Laughter of the Gods," in Friendship (Blanchot 177-80); and Gilles Deleuze, Difference and Repetition (Deleuze 2011, 162 n.28). See also Klossowski's "Nietzsche, Polytheism, and Parody" in Such a Deathly Desire (Klossowski 2007, 112-3).

` To some extent this conception is suggestive of Agamben's later critique of Gershom Scholem's being in force without significance (Agamben 1998, 50-1).

${ }^{\text {vi }}$ This sentiment, though to some extent connoting Hegel, recalls Agamben's later commentary on Kafka's "enigmatic" statement that the Messiah will only come after his arrival, and of the beatitude of a potentiality "that comes only after the act" (Agamben 1998, 57; 2005a, 56).

vii Agamben explicitly likens Nietzsche's eternal return to Deleuze's difference and repetition in the essay "Difference and Repetition: On Guy Debord's Films," which restates many of the ideas present in the essays on gesture. See Giorgio Agamben, "Difference and Repetition: On Guy Debord's Films" (Agamben 2004, 315-6).

viii The quote rather cryptically reads: "The idea of the eternal return is primarily an idea of the like, something in the order of a total image, or, to use Benjamin's words, a dialectical image. And only in this context, perhaps, does the eternal return take on its essential significance." This brief comment is the only mention of Benjamin in the essay. ${ }^{\text {ix }}$ Unpublished in Benjamin's lifetime, Agamben has recently compiled a new Italian edition of this work.

${ }^{x}$ An interesting counterpoint to Benjamin's understanding of the redemptive aspect of the eternal return presented here is Deleuze's reading of Nietzsche's will to power as the self-dissolution of mechanical order by thought (Deleuze 2006, 44-5).

${ }^{x i}$ Bartleby and the eternal return are again put into play against each other in the first of Agamben's multi-volume Homo Sacer series, which, at the time of writing, nears completion. At 
the conclusion of the chapter on "Potentiality and Law," Agamben acknowledges Nietzsche's amor fati as "an attempt to conceive of being beyond the principle of sovereignty" that renders potentiality and actuality indistinguishable even as it subsumes contingency into necessity. The figure of Bartleby, however, comes closest to achieving this end if still falling short of freeing itself from the sovereign ban, the task that Agamben claims as his own (Agamben 1998, 48). Of perhaps greater significance to the argument presented in this paper is Agamben's thesis of a Benjaminian resolution of life into writing that is advanced in his exegesis of a series of letters exchanged between Benjamin and Gershom Sholem in 1934. Agamben argues that Benjamin's comments on the tendency of Kafka's allegories toward transforming life into scripture evoke the total resolution of life into law such that the sovereign ban, which determines the relation between the two terms, dissolves in a "real state of exception" (54-5). Without here endeavoring to advance a counter-reading on the subject, for the sake of argument, one may provisionally suggest that such a hypothetical Benjaminian resolution of life into writing would not amount to a recuperation of the inscriptive from the Strafe des Nachsitzens. But, rather, in its obliteration of the law's being-in-force-without-significance, it transforms the transcendent inscriptive form of language into an immanent enunciative one. Agamben himself makes a similar argument in his essay of 1983, "Language and History: Linguistic and Historical Categories in Benjamin's Thought" (Agamben 1999b, 48-61). See also Daniel Heller-Roazen's introduction to Potentialities in which he critiques Agamben's thought in relation to Benjamin's description of historical method as "to read what was never written," a citation of Hofmannsthal found in "Theses on the Philosophy of History" (1-23).

${ }^{x i i}$ While Durantaye elaborates Agamben's criticism of the mechanical quality of deconstruction (Durantaye, 189), the textual evidence suggests that Agamben's own work at times exhibits this 
very quality. In particular, Agamben delineates a dualistic structure of linguistic experience in which the two sides, oath and grace, exist in dialectical equilibrium of noncoincidence in Time That Remains: A Commentary on the Letter to the Romans (Agamben 2005c, 134-6), and even in State of Exception, as he denounces the juridico-politcal system as a "killing machine," there is nonetheless some suggestion of its prior mechanical functionality, even if we can no longer maintain it as operable (Agamben 2005b, 85-7). These are but two examples of this mechanical quality rearing its head in Agamben's counter-mechanical formulas. I have written in detail elsewhere on this matter; see "Time and Presence in Agamben's Critique of Deconstruction" (Doussan 2013).

\section{Works Cited}

Agamben, Giorgio. 1988. "The Eternal Return and the Paradox of Passion.” Nietzsche in Italy, 917. Ed. Thomas Harrison. Saratoga, CA: Anma Libri.

Agamben, Giorgio. 1991. Language and Death: The Place of Negativity. Trans. Karen E. Pinkus with Michael Hardt. Minneapolis: University of Minnesota Press.

Agamben, Giorgio. 1998. Homo Sacer: Sovereign Power and Bare Life. Trans. Daniel HellerRoazen. Stanford, Calif.: Stanford University Press.

Agamben, Giorgio. 1999a. The Man Without Content. Trans. Georgia Albert. Stanford, Calif.: Stanford University Press.

Agamben, Giorgio. 1999b. Potentialities: Collected Essays in Philosophy. Ed., trans. Daniel Heller-Roazen. Stanford, Calif.: Stanford University Press. 
Agamben, Giorgio. 1999c. Remnants of Auschwitz: The Witness and the Archive. Trans. Daniel Heller-Roazen. New York: Zone Books.

Agamben, Giorgio. 2000. Means Without End: Notes on Politics. Trans. Vincenzo Binetti and Cesare Casarino. Minneapolis: University of Minnesota Press.

Agamben, Giorgio. 2004. “Difference and Repetition: On Guy Debord's Films.” In Guy Debord and the Situationists International: Texts and Documents. Ed. Tom McDonough, 313-19. Cambridge, Mass.: MIT Press.

Agamben, Giorgio. 2005a. The Coming Community. Trans. Michael Hardt. Minneapolis: University of Minnesota Press.

Agamben, Giorgio. 2005b. State of Exception. Trans. Kevin Attell. Chicago: University of Chicago Press.

Agamben, Giorgio. 2005c. The Time That Remains: A Commentary on the Letter to the Romans. Trans. Patricia Dailey. Stanford, CA: Stanford University Press.

Agamben, Giorgio. 2007. Infancy and History: On the Destruction of Experience. Trans. Liz Heron. London and New York: Verso.

Agamben, Giorgio. 2009. The Signature of All Things: On Method. Trans. Luca DiSanto with Kevin Attell. New York: Zone Books.

Agamben, Giorgio. 2013. The Highest Poverty: Monastic Rules and Form-of-Life. Trans. Adam Kotsko. Stanford, Calif.: Stanford University Press.

Aristotle. 1984. Complete Works of Aristotle: The Revised Oxford Translation. Edited by Jonathan Barnes. 2. Vols. Princeton, NJ and Chichester: Princeton University Press. 
Benjamin, Walter. 1994. The Correspondence of Walter Benjamin 1910-1940. Ed. Ann.

Gershom Sholem and Theodor W. Adorno. Trans. Manfred R. Jacobsen and Evelyn M. Jacobson. Chicago: University of Chicago Press.

Benjamin, Walter. 1998. The Origin of German Tragic Drama. Trans. John Osborne. London and New York: Verso.

Benjamin, Walter. 2002. The Arcades Project. Trans. Howard Eiland and Kevin McLaughlin. Paperback ed. Cambridge, Mass. and London: Harvard University Press.

Benjamin, Walter. 2006. Selected Writings Volume 4, 1938-1940. Ed. Howard Eiland and Michael W. Jennings. Trans. Edmund Jephcott and Others. Paperback ed. Cambridge, Mass. and London: Harvard University Press.

Blanchot, Maurice. 1997. Friendship. Trans. Elizabeth Rottenberg. Stanford, Calif.: Stanford University Press.

Blanqui, Louis-Auguste. 2013. Eternity by the Stars: An Astronomical Hypothesis. Trans. Frank Chouraqui. New York: Contra Mundum.

Deleuze, Gilles. 2006. Nietzsche and Philosophy. Trans. Hugh Tomlinson. London and New York: Continuum.

Deleuze, Gilles. 2011. Difference and Repetition. Trans. Paul Patton. London and New York: Continuum.

Doussan, Jenny. 2013. "Time and Presence in Agamben's Critique of Deconstruction." Cosmos and History: The Journal of Natural and Social Philosophy 9, no. 1: 183-202.

De La Durantaye, Leland. 2009. Giorgio Agamben: A Critical Introduction. Stanford, Calif.: Stanford University Press. 
Heidegger, Martin. 1991. Nietzsche: Volumes One and Two. Trans. David Farrell Krell. San Francisco: Harper Collins.

Klossowski, Pierre. 1997. Nietzsche and the Vicious Circle. Trans. Daniel W. Smith.

Klossowski, Pierre. 2007. Such a Deathly Desire. Trans. Russell Ford. Albany: State University of New York Press.

Nietzsche, Friedrich. 1974. The Gay Science: with a Prelude in German Rhymes and an Appendix of Songs. Trans. Walter Kaufmann. New York: Vintage.

Plato. 1973. The Collected Dialogues including the Letters. Edited by Edith Hamilton and Huntington Cairns. Princeton, NJ: Princeton University Press.

Raulff, Ulrich. 2004. "Interview with Giorgio Agamben - Life, A Work of Art Without an Author: The State of Exception, the Administration of Disorder and Private Life." In "Security, Democracy, and the Future of Freedom," special issue, German Law Journal 5, (May) no. 5: 614 . 